\title{
AGRÁRTÁJHOZ KÖTŐDŐ MADÁRFAJOK („FARMLAND BIRDS”) ÁLLOMÁNYÁNAK VÁLTOZÁSA, HELYZETE EURÓPÁBAN
}

\author{
Németh Tamás Márton \\ Soproni Egyetem, Vadgazdálkodási és Gerinces Állattani Intézet \\ University of Sopron, Institute of Wildlife Management and Vertebrate Zoology \\ H-9400 Sopron, Bajcsy-Zs u. 4., Hungary \\ e-mail: tomanemeth@gmail.com
}

\begin{abstract}
NÉMETH T.M: POPULATION CHANGES AND STATUS OF FARMLAND BIRDS IN EUROPE - A REVIEW. Hungarian Small Game Bulletin 13: 143-160. http://dx.doi.org/10.17243/mavk.2017.143

The present review aimed to summarize the available evidence on farmland bird populations and their changes over the past decades in Europe. Firstly, a short historical background of the European agricultural intensity is presented. Secondly, the European Farmland Bird Index, published papers and grey literatures were searched and studied to show the recent population trends and population sizes of farmland bird species ( 37 species selected for monitoring by the EU and more specifically focusing on 10 bird species breeding in Hungary). Finally, a short summary and a conclusion are given.
\end{abstract}

KULCSZAVAK: Európai Unió, állománycsökkenés, agrárintenzifikáció, Európai Madárszámlálási Tanács

KEY WORDS: European Union, population decline, agricultural intensification, European Bird Census Council

\section{BEVEZETÉS}

Az elmúlt néhány évtizedben egyre fontosabbá vált a Föld növény- és állatfajainak védelme és mind a tudomány, mind a társadalom felismerte, hogy egyes fajok megörzése beavatkozások nélkül elkerülhetetlen. Az emberi tevékenységek hatása az egész világon drasztikus változásokat vitt véghez - például élöhelyek eltünése vagy fajok kipusztulása -, de ez a folyamat nem állt még meg (PERSÁNYI, 1988; SMITH et al., 1993). Az élőhelyek átalakításával járó hatások a geológiai múltban (természeti katasztrófa) végbement kihalásokhoz hasonlíthatók (LÁJER, 1994; STANDOVÁR \& PRIMACK, 2001).

Az összefüggő élőhelyek feldarabolódása egyrészről természetes folyamat - például szélvihar vagy tüz alkalmával (WRIGHT, 1974; PICKETT \& THOMPSON, 1978) - de a legnagyobb mértékủ élöhely-fragmentációk okának az emberi földhasználat terjeszkedését és intenzifikációját tartják (BURGESS \& SHARPE, 1981; SISK et al., 1994). WILCOX \& MURPHY (1985) az élőhely-fragmentációnak három fö típusát jelölte meg: az eredeti élőhely méretének csökkenése vagy eltünése, az élőhelyfoltok méretének zsugorodása és az élőhelyfoltok elszigeteltségének megnövekedése. Természetesen a három komponens egymással szorosan összefügg, azonban az élőhelyek csökkenése, illetve eltünése játssza a legnagyobb szerepet a fajok kihalásában (GROOMBRIDGE, 1992; BIBBY, 1994; THOMAS \& MORRIS, 1994).

Az emberi beavatkozások következtében átalakított élöhelyek és életfeltételek a teljes állatvilágot érintették (PECHMANN et al., 1991; ANDRÉN, 1994; SCHNEIDER \& YODZIS, 1994; 
ThOMAS \& Morris, 1994; Delis et al., 1996; GIBBS, 1998; AlfORD \& RichARDS, 1999; THOMAS et al., 2004). Az emberi átalakítások másik jellegzetessége volt, hogy hasznos és káros kategóriákat hoztak létre (STANDOVÁR \& PRIMACK, 2001), amelyek nagyban átalakították a faj és állomány viszonyokat. Példa erre a hazai korai madárvédelmi intézkedés bevezetése is (CHERNEL, 1899; HERMAN, 1901).

Az átalakításba vont területek egyik legfőbb célja a müvelt termőföldek nyerése volt, amely több ezer évvel ezelött kezdődött meg (VERA, 2000). Így a kezdetben extenzív művelésnek nevezhető agrárterületeken fellelhetők voltak még a nyílt élőhelyekre jellemző fauna elemek (SUTHERLAND, 2002). A további fejlődést követve ezeken az agrártájakon egy teljesen új és jellegzetes növény- és állatközösség alakult ki (POTTS, 1991). Azonban ez a rendszer a mezőgazdasági művelésben bekövetkező változások hatására, a 20. század második felére majdnem összeomlott (POTTS, 1997; REIDSMA et al., 2006) és ez súlyos hatást gyakorolt az élővilág biodiverzitásra (KREBS et al., 1999; TILMAN et al., 2001; BENTON et al., 2003). A változások (értsd: mezőgazdaság intenzifikáció) - túlzott vegyszer és mütrágya használat, mozaikos tájszerkezet helyett nagytáblás kultúrák, nagymértékü gépesítés, túlzott legeltetés ebben az időszakban (1940-es és 1950-es évek) Nyugat- és Észak-Európában (EU15) voltak a legszembetünőbbek (CHAMBERLAIN \& FulLER, 2000; TILMAN et al., 2002; BENTON et al., 2003; KLEIJN \& BÁLDI, 2005; TsChARNTKE et al., 2005; DONALD et al., 2006). A probléma tényleges azonosítása ugyanakkor csak az 1990-es években történt meg (BENTON et al., 2003). Így az agrártáj („farmland”) biológiai sokféleségében bekövetkezett csökkenést szinte egyszerre bizonyították a növény- (ANDREASEN et al., 1996; SOTHERTON \& SELF, 2000), a rovar- (SOTHERTON \& SELF, 2000), a madár- (FULLER et al., 1995; SIRIWARDENA et al., 1998; DONALD et al., 2001) és az emlősfajoknál (FLOWERDEW, 1997). BENTON et al. (2003) szerint minden kétség nélkül kijelenthető, hogy a fö ok a mezőgazdaság intenzifikációja és a probléma megoldása a természetvédelmi biológia talán legnagyobb kihívásává vált (DONALD et al., 2001; FIRBANK, 2005).

Az Európai Unió területének kb. 45\% művelés alatt áll és az európai földhasznosítás kb. 21\%-án (kb. 33 millió ha) gabonatermelés folyik (EUROSTAT, 2010), ami a madarak szempontjából igen jelentős. Az európai mezei madárfajok vagy az agrártájhoz kötődő madárfajok („farmland birds”) elmúlt évtizedekben megfigyelt állománycsökkenésének (TUCKER \& HEATH, 1994; SiRIWARDENA et al., 1998; PitKÄNEN \& TIAINEN, 2001; DonAlD et al., 2006; WRETENBERG et al., 2006; REIF et al., 2008) okaként is elsődlegesen a mezőgazdaság intenzifikációját tartják (CHAMBERLAIN et al., 2000; DONALD et al., 2001; GREGORY et al., 2005). A téma néhány évtizede már a természetvédelmi biológia egyik legfontosabb kérdése (DONALD et al., 2002; GREGORY et al., 2005; BENTON, 2007), jelen munka az előbbiekben említett változást és helyzetét tekinti át.

\section{AZ EURÓPAI AGRÁRINTENZIFIKÁCIÓ RÖVID ÁTTEKINTÉSE}

A földművelést megelőző időben Európa jókora részét még nyílt élőhelyek borították (SVENNING 2002) és az ezekhez adaptálódott fajok helyzete napjainkban már a mezőgazdasági technológia gyakorlatától függ (SUTHERLAND, 2002).

A termelő gazdálkodásra az ember feltételezhetően a neolitikumban tért át (SUTHERLAND, 2002), de az ehhez köthető átalakulások - drasztikus beavatkozások, gyors ütemü agrárfejlesztés -, azonban csak a 20. század második felében érték el az EU15 országait (PAIN et al., 1997). A változásokat, mint például túlzott vegyszer- és mütrágyahasználat, egyszerüsödő vetésforgók, nagymértékủ gépesítés, nagytáblás kultúrák 
(1. ábra), a homogenizáció, a korábban nem használt földek termelésbe vonása (STOATE et al., 2001; ROBINSON \& SUTHERLAND, 2002; NEWTON, 2004; WILSON et al., 2005) csak tovább erősítette az 1957-ben bevezetett Közös Agrárpolitika - KAP (Common Agricultural Policy CAP) (STOATE et al., 2001), ami komoly természeti károkat okozott (DonALD et al., 2006).

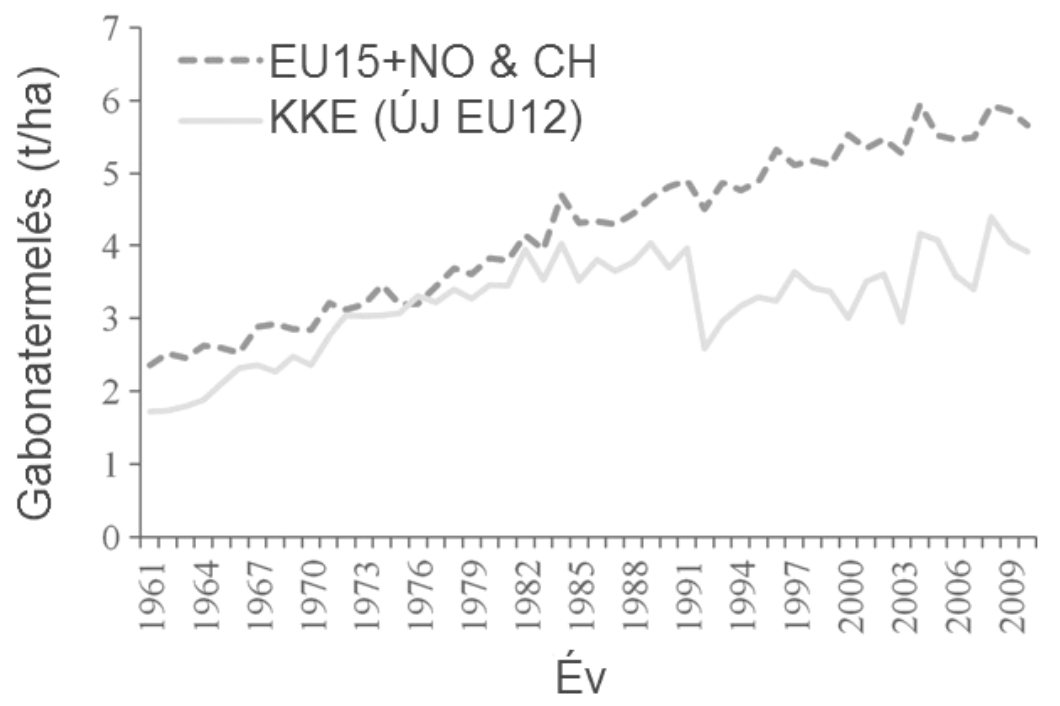

1. ábra: Gabonatermelés változása Európában (Forrás: FAOSTAT, www.faostat3.fao.org)

(EU15= EU tagállamok, NO - Norvégia, CH - Svájc, KKE - Közép- és Kelet-Európa)

Figure 1: Changes of cereal yield in Europe (Source: FAOSTAT, www.faostat3.fao.org)

(EU15= EU Member States, NO - Norway, $\mathrm{CH}-$ Switzerland, KKE - Mid- and Central Europe $)$

Egyik eredménye, hogy a kontinens országaiban az agrártájhoz kötődő madárfajok állománya az 1970-es évektől drasztikus csökkenésnek indult (POTTS, 1986; SVENSSON, 1995; SIRIWARDENA et al., 1998). Ezen időszak alatt Közép- és Kelet-Európában (egykori szocialista országok) is megváltoztak a mezőgazdaság viszonyai (például kis családi gazdaságok helyett termelöszövetkezetek, nagytáblás müvelés térhódítása), majd az 1960-70es évektől megkezdett nagyfokú vegyszer- és mütrágyahasználat tovább erősítette az ágazat intezifikációját (ÁNGYÁN et al., 2003). Annak ellenére, hogy 1960 és 1980 között a mezőgazdaság termelés növekedésének aránya szinte megegyezett a kettéválasztott Európában (VERHULST et al., 2004), a Közép- és Kelet-Európa agrártáj madárpopulációja kisebb veszteséget mutatott (DONALD et al., 2001).

A rendszerváltáskor az agrárium teljesítménye hirtelen visszaesett - például a mütrágya használata is nagymértékben lecsökkent (2. ábra) -, ami pozitív hatással volt az agrártáj élővilágának biodiverzitására (BÁLDI \& FARAGÓ, 2007; LIIRA et al., 2008). NyugatEurópában (EU15) az 1980-as évekre bebizonyosodott a KAP hibája, és az egyre növekvő környezettudatosság a rendszer újragondolását eredményezte (BIGNAL et al., 2001). 1992-ben megindultak az agrár környezetvédelmi programok, amelyek célja az volt, hogy a gazdálkodók a termelés mellett a biodiverzitás védelmét is elösegítsék. A 2000-es években újabb reformok és kompenzációk jelentek meg (HENLE et al., 2008), de a biológiai sokféleség megörzésének eredményessége vitatott volt a tagországok között (PEACH et al., 2001; KLEIJN \& SuTHERLAND, 2003; KLEIJN et al., 2004). 2004-ben 10, majd 2007-ben 2 országgal bővült az Európai Unió. 


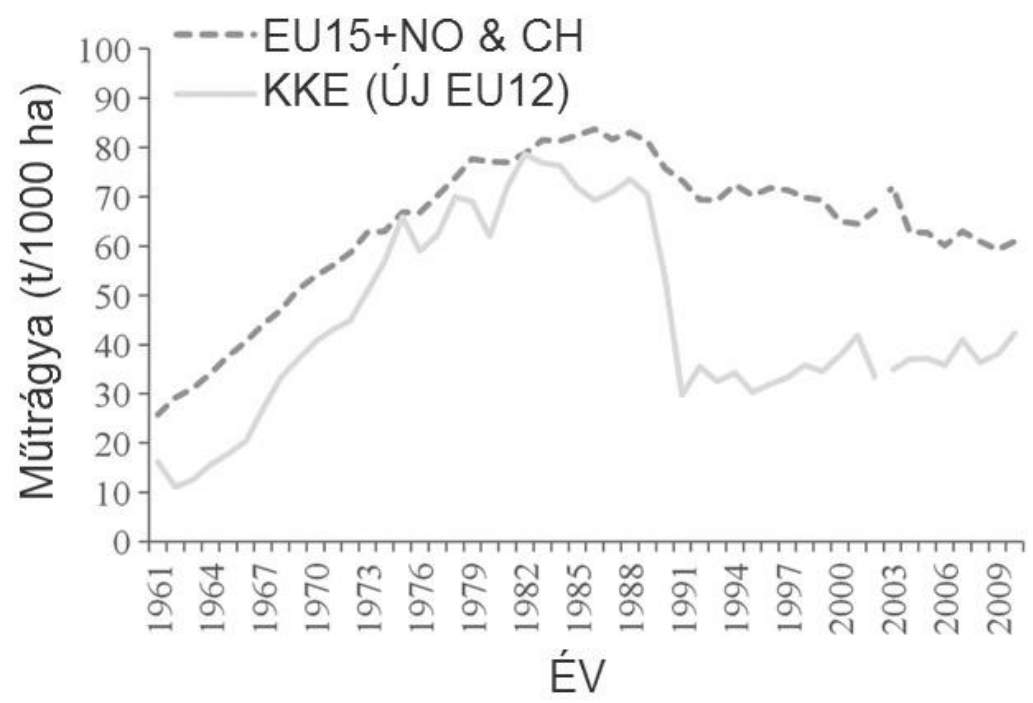

2. ábra Mütrágya-kibocsátás változása Európában (Forrás: FAOSTAT, www.faostat3.fao.org) Figure 2: Changes of N fertiliser consumption in Europe (Source: FAOSTAT, www.faostat3.fao.org)

Az újonnan belépő országok mindegyike kevésbé intenzív mezőgazdasággal rendelkezett, mint az EU15 (DoNALD et al., 2002), emellett mind a 12 csatlakozó támogatta az agrártájhoz kötődő madárfajok állományának védelmét (BIRDLIFE INTERNATIONAL, 2004), ám a csatlakozással a KAP rendszer problémáival és veszélyeivel is szembesülniük kellett.

Az utóbbi években megjelent vizsgálatok (hazai és külföldi) alapján egyértelmü következtetéseket nem vonhatunk még le, de az átvett KAP rendszer negatív hatásai megmutatkoznak az új tagállamok madárállományának változásaiban (BÁLDI \& BATÁRY, 2011; TRYJANOWSKI et al., 2011; FARAGÓ et al., 2012; SANDERSON et al., 2013).

\section{AZ EURÓPAI AGRÁRTÁJHOZ KÖTŐDŐ MADÁRFAJOK ÁLLOMÁNYÁNAK VÁLTOZÁSA}

A 1990-es évek elejéig Európa különböző országaiban már felhívták a figyelmet az agrárintenzifikáció és az agrártájhoz kötődő madárfajok problémájára (POTTS, 1970; GALBRAITH, 1988; SCHLÄPFER, 1988; DONÁZAR et al., 1993; BERG \& PÄRT, 1994). Habár a negatív változásokat (3. ábra) főként az Egyesült Királyságból jelezték (GREGORY et al., 2004), mégis itt is csak az 1990-es évek közepére vált nyilvánvalóvá a kialakult helyzet (FULLER et al., 1995). Mivel a különböző élőhelyekhez kötődő madárfajok állománytrendjei alapján jól lehet az adott élőhely állapotára jellemző biodiverzitás indikátor indexet alkalmazni mind országos mind kontinentális léptékben, a 2000-es évektől megkezdték felhasználásukat (VAN STRIEN et al., 2001; GREGORY et al., 2005; WINKLER \& FARAGÓ, 2011; EBCC, 2012; SZÉP et al., 2012; STJERNMAN et al., 2013). 


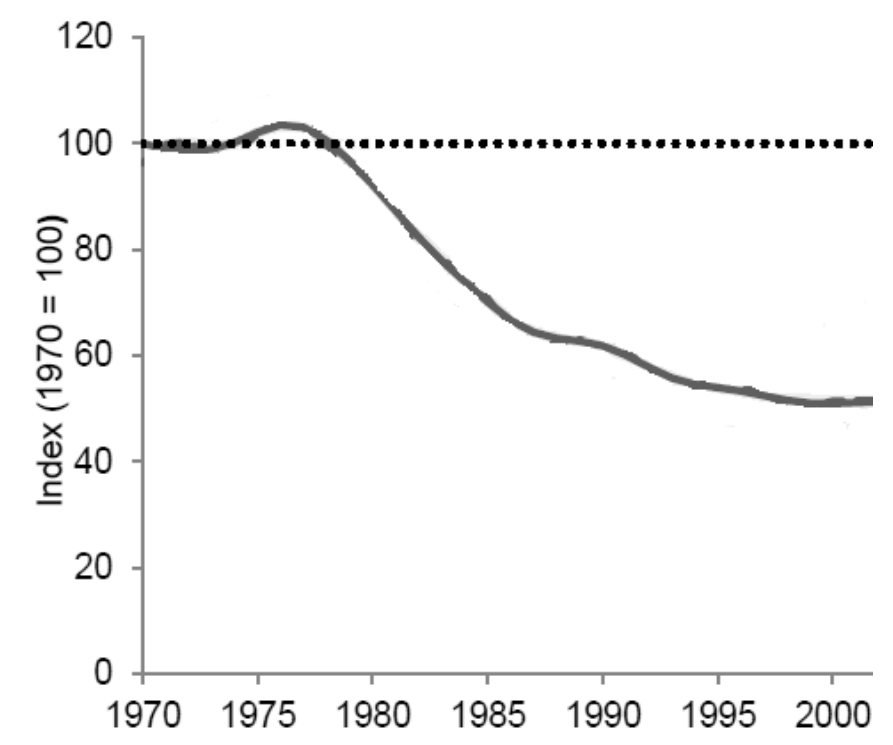

3. ábra: 19 mezei madárfaj populációjának változása az Egyesült Királyságban (Forrás: DEFRA, www.gov.uk/defra)

Figure 3: Population index change of 19 farmland bird species in the United Kingdom (Source: DEFRA, www.gov.uk/defra)

\subsection{AZ EURÓPAI POPULÁCIÓS ADATOK ÁTTEKINTÉSE}

A külföldi szakirodalomban használt „farmland birds” kifejezés egy olyan gyüjtőfogalom, amely alatt azon madárfajokat értjük, amelyek fészkelésük vagy táplálkozásuk révén feltétlenül kötődnek a mezőgazdasági élőhelyekhez. Az egyes országokon belül a mezei madárfajok száma eltérő, így az európai adatok egységesítése érdekében a madárvédelmi szervezetek és az Európai Unió 37 madárfaj (1. táblázat) állományváltozását vizsgálta és vizsgálja. A korábbi adatoknál ezenkívül eltérés mutatkozik a vizsgált országok számában is (2004-es és 2007-es EU bővítés), ezért a korábbi EU-s adatok bemutatásakor, ez is feltüntetésre kerül. Mivel a hazai agrártájhoz kötődő madárfajokban is megfigyelhető eltérés, ezért további 10 faj (1. táblázat) esetében mutatom be az állomány helyzetét (félkövér betütípussal kiemelve). A kiválasztás a saját terepi tapasztalatok alapján történt.

Az Európai Unió agrár-környezetvédelmi indikátorai között az egyik legfontosabb az agrártájhoz kötődő madárfajok állománytrendje. Az EUROSTAT (2010) által közölt grafikon alapján egyértelmủ az 1990 előtti és utáni visszaesés (4. ábra). Jól látszik a 2. fejezetben már említett drasztikus csökkenés, amely iránya megegyezik az angliai adatokkal (lásd 3. ábra). Sajnos az EUROSTAT (2010) nem tüntette fel, hogy 1990 elött melyik 7 országból származtak az adatok. 


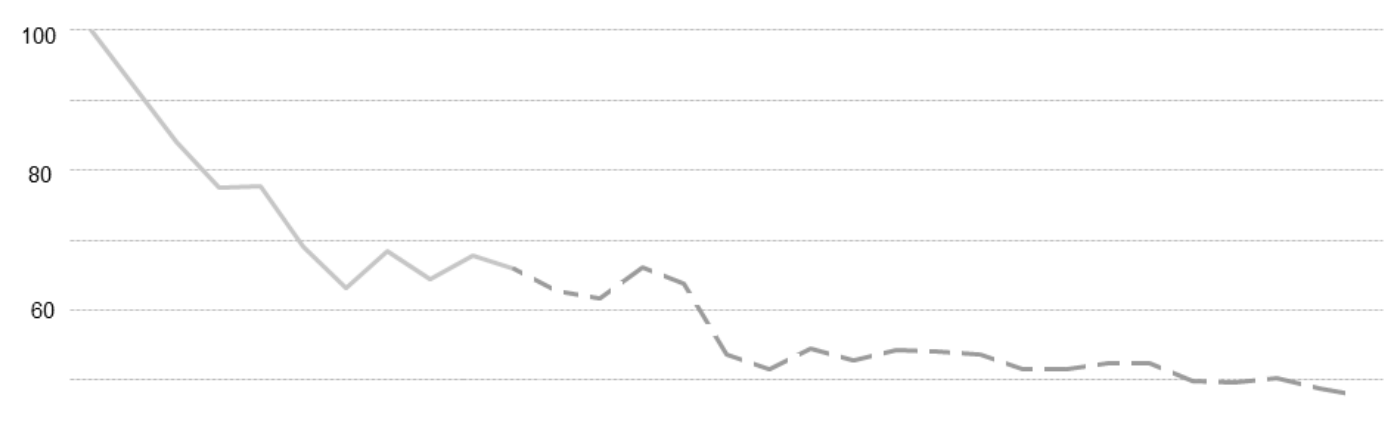

40

20

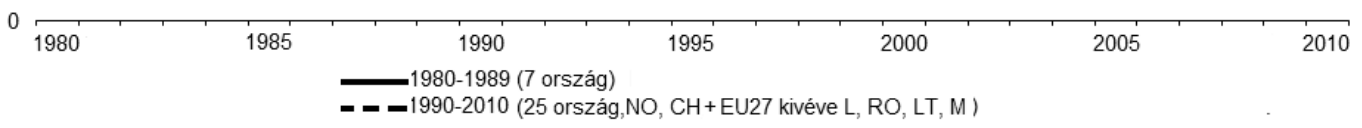

4. ábra: Mezei madárfajok populációtrendje Európában 1980-2010 között (Forrás:

EUROSTAT, www.epp.eurostat.ec.europa.eu)

Figure 4: Population trend of farmland birds in Europe (1980-2010) (Source: EUROSTAT,

www.epp.eurostat.ec.europa.eu)

Az Európai Madárszámlálási Tanács (EBCC - European Bird Census Council) által elérhető adatsorok részletesebbek. Az európai állományváltozást 25 országra ( $\mathrm{NO}$ - Norvégia, $\mathrm{CH}-$ Svájc + EU27 kivéve L - Luxemburg, LT - Litvánia, M - Málta, RO - Románia), 1980-2010 közötti időszakra és a fentebb említett 37 fajra adja meg. Az EBCC (2012) szerint ezalatt a ciklus folyamán 22 faj populációja csökkenő, 8 fajé növekvő és 6 fajé stabil trended mutatott. 3 faj esetében pedig bizonytalan. Az erre az időszakra számolt (első év és utolsó vizsgált év közti különbség) index $-51 \%$ (ЕBCC 2012).

Közép- és Kelet-Európában az 1970-80-as évek (intenzív szocialista mezőgazdaság időszaka) az agrártájhoz kötődő madárfajok állománycsökkenését hozta (BÁLDI \& FARAGÓ, 2007; REIF et al., 2008). Ezt bizonyítja az EBCC (2012) felmérése is (27 madárfajt vizsgálva): 1982-1990 közötti -20\%-os populációs index (5. ábra). 1980-1990 között Nyugat-Európában (EU15 kivétel Luxemburg) 36 mezei madárfaj helyzete még mindig rossz volt (-31\%-os mutató) (5. ábra). A szocialista rendszer összeomlásával, 1990-2004 között a csökkenés mérséklődött (-12\%). Az Európai Unióba 2004-ben újonnan belépő 10 országnak (köztük Magyarországnak is) a KAP rendszert is be kellett építenie a mezőgazdasági politikájába. BÁLDI et al. (2005) és DONALD et al. (2006) a korábbi EU-s tapasztalatok alapján a KAP rendszer várható negatív hatásaira hívták fel a figyelmet. Az EBCC (2012) alapján 2004-2010 között az agrártájhoz kötődő madárfajok állománytrendje további csökkenést mutat (6. ábra). Ezt erősítik a hazai adatok (6. ábra): 16 mezei madárfaj populációs indexe 2005 óta csökken (BÁLDI \& SzÉP, 2009). SzÉP et al. (2012) 1999-2012 közti adatok elemzésével szintén csökkenő trendet állapítottak meg. 

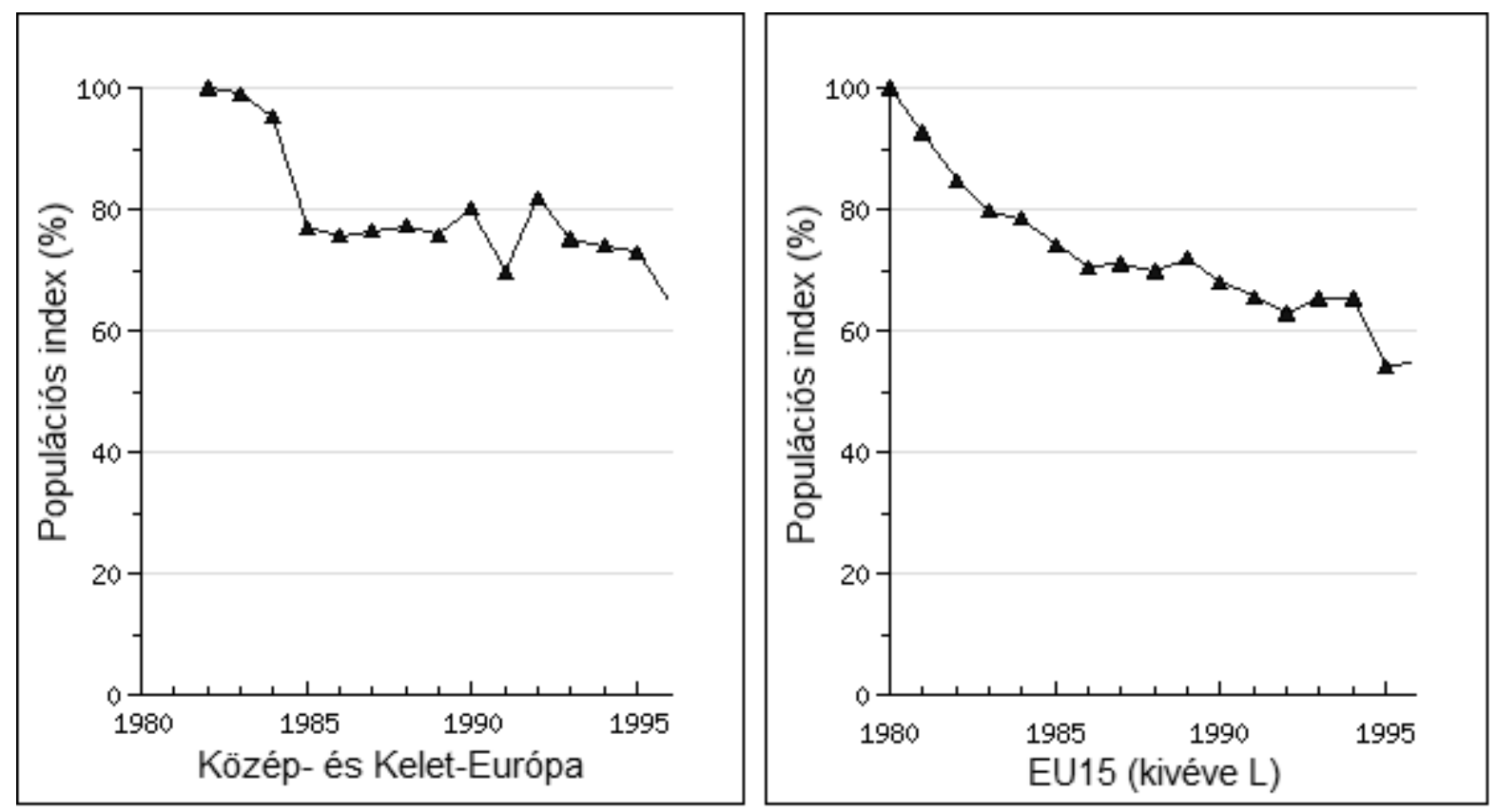

5. ábra: Közép- és Kelet-Európa és az EU15 különbsége az agrártájhoz kötődő madárfajok tekintetében (Forrás: EBCC, www.ebcc.info)

Figure 5. Change in farmland bird population index in Central and Eastern Europe and in the EU15 countries - except Luxembourg - (Source: EBCC, www.ebcc.info)
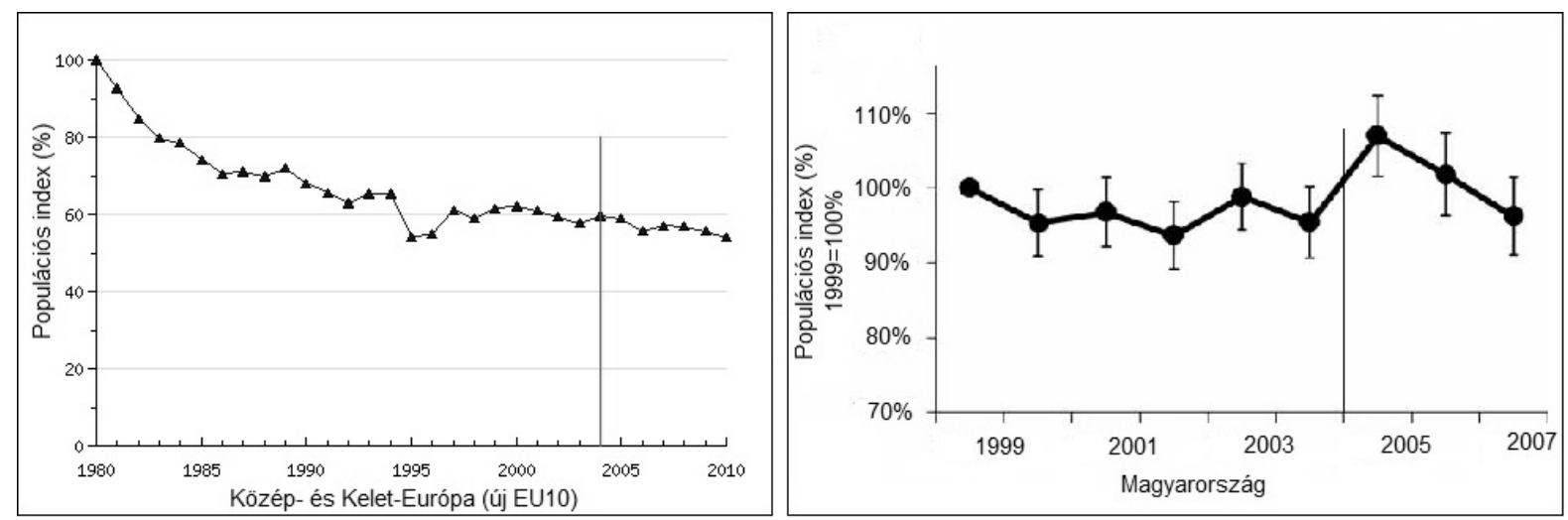

6. ábra: Az Európai Unióhoz való csatlakozást követő populációs index

(Forrás: EBCC, www.ebcc.info; BÁLDI \& SzÉP (2009)

Figure 6. Change in farmland bird population index after the accession of/to the EU (Source: EBCC, www.ebcc.info; BÁLDI \& SZÉP, 2009)

\subsection{MEZEI MADÁRFAJOK POPULÁCIÓS TRENDJE EURÓPÁBAN}

A rendelkezésemre álló adatbázisok adatai alapján (BIRDLIFE, EBCC, MME MMM) állítottam össze a 47 faj populációjára vonatkozó információkat (1. táblázat). A táblázatba a legfrissebb BIRDLIFE adatok kerültek, de pontos időszakot nem lehet behatárolni, mint a többi esetben, mivel fajonként és országonként eltérő időszakokat tüntettek fel. 
1. táblázat: Faj szintű populációs trendek Európában és Magyarországon

Table 1: Population trends of farmland bird species in Europe and Hungary

\begin{tabular}{|c|c|c|c|c|}
\hline \multirow[b]{2}{*}{$\begin{array}{l}\text { Faj } \\
\text { Species }\end{array}$} & \multicolumn{2}{|c|}{ Európai / Europaean } & \multicolumn{2}{|c|}{ Nemzeti / National } \\
\hline & EBCC (1980-2010) & $\begin{array}{c}\text { BirdLife (2015) EU27 } \\
\text { /EU }\end{array}$ & $\begin{array}{c}\text { MME MMM } \\
(1999-2014)\end{array}$ & $\begin{array}{c}\text { Bonni } \\
\text { Jelentés } \\
(2011-2014)\end{array}$ \\
\hline Alectoris rufa & Mérsékelt csökkenés & Csökkenö/Csökkenő & Nincs adat & - \\
\hline Perdix perdix & Erős csökkenés & Csökkenö/Csökkenő & Mérsékelt csökkenés & - \\
\hline Ciconia ciconia & Mérsékelt növekedés & Növekvő/Növekvő & Bizonytalan & - \\
\hline Falco tinnunculus & Mérsékelt csökkenés & Csökkenő/Csökkenő & Stabil & - \\
\hline Burhinus oedicnemus & Stabil & Növekvő/Növekvő & Nincs adat & - \\
\hline Vanellus vanellus & Mérsékelt csökkenés & Csökkenő/Csökkenő & Mérsékelt csökkenés & - \\
\hline Limosa limosa & Mérsékelt csökkenés & Csökkenő/Csökkenő & Bizonytalan & - \\
\hline Uрира ерорs & Bizonytalan & Stabil/Stabil & Stabil & - \\
\hline Streptopelia turtur & Mérsékelt csökkenés & Csökkenő/Csökkenő & Stabil & - \\
\hline Alauda arvensis & Mérsékelt csökkenés & Csökkenő/Csökkenő & Mérsékelt csökkenés & - \\
\hline Calandrella brachydactyla & Stabil & Stabil/Nem ismert & Nincs adat & - \\
\hline Melanocorypha calandra & Mérsékelt csökkenés & Csökkenő/Csökkenő & Nincs adat & - \\
\hline Galerida cristata & Mérsékelt csökkenés & Csökkenö/Csökkenő & Mérsékelt csökkenés & - \\
\hline Galerida theklae & Mérsékelt növekedés & Növekvő/Növekvő & Nincs adat & - \\
\hline Hirundo rustica & Stabil & Csökkenő/Csökkenő & Mérsékelt csökkenés & - \\
\hline Anthus campestris & Bizonytalan & Stabil/Nem ismert & Bizonytalan & - \\
\hline Anthus pratensis & Mérsékelt csökkenés & Csökkenő/Csökkenő & Bizonytalan & - \\
\hline Motacilla flava & Mérsékelt csökkenés & Csökkenö/Csökkenő & Stabil & - \\
\hline Saxicola rubetra & Mérsékelt csökkenés & Csökkenő/Csökkenő & Mérsékelt csökkenés & - \\
\hline Saxicola torquata & Stabil & Csökkenö/Csökkenő & Mérsékelt csökkenés & - \\
\hline Oenanthe hispanica & Mérsékelt csökkenés & Csökkenő/Stabil & Nincs adat & - \\
\hline Sylvia communis & Mérsékelt növekedés & Stabil/Stabil & Mérsékelt csökkenés & - \\
\hline Lanius collurio & Stabil & Csökkenő/Stabil & Mérsékelt csökkenés & - \\
\hline Lanius minor & Mérsékelt csökkenés & Nem ismert/Stabil & Mérsékelt csökkenés & - \\
\hline Lanius senator & Mérsékelt csökkenés & Csökkenő/Csökkenő & Nincs adat & - \\
\hline Corvus frugilegus & Mérsékelt növekedés & Csökkenö/Csökkenő & Bizonytalan & - \\
\hline Sturnus unicolor & Mérsékelt növekedés & Növekvő/Növekvő & Nincs adat & - \\
\hline Sturnus vulgaris & Mérsékelt csökkenés & Csökkenő/Csökkenő & Mérsékelt növekedés & - \\
\hline Passer montanus & Mérsékelt csökkenés & Csökkenő/Bizonytalan & Mérsékelt növekedés & - \\
\hline Petronia petronia & Stabil & Csökkenő/Stabil & Nincs adat & - \\
\hline Carduelis cannabina & Mérsékelt csökkenés & Csökkenö/Csökkenő & Stabil & - \\
\hline Emberiza cirlus & Mérsékelt növekedés & Stabil/Stabil & Nincs adat & - \\
\hline Emberiza citrinella & Mérsékelt csökkenés & Csökkenő/Csökkenő & Stabil & - \\
\hline Emberiza hortulana & Erős csökkenés & Csökkenő/Csökkenő & Nincs adat & - \\
\hline Emberiza melanocephala & Bizonytalan & Nem ismert/Csökkenő & Nincs adat & - \\
\hline Miliaria calandra & Mérsékelt csökkenés & Stabil/Stabil & Mérsékelt csökkenés & - \\
\hline Serinus serinus & Mérsékelt csökkenés & Csökkenő/Csökkenő & Mérsékelt csökkenés & - \\
\hline
\end{tabular}


Az 1. táblázat folytatása - Table 1 cont.

\begin{tabular}{lcccc}
\hline \multirow{2}{*}{$\begin{array}{l}\text { Faj } \\
\text { Species }\end{array}$} & \multicolumn{2}{c}{ Európai / Europaean } & \multicolumn{2}{c}{ Nemzeti / National } \\
\cline { 2 - 5 } & EBCC (1980-2010) & BirdLife (2015) EU27 & MME MMM & $\begin{array}{c}\text { Bonni } \\
\text { Jelentés } \\
(1999-2014)\end{array}$ \\
\hline Coturnix coturnix & Nincs adat & Csökkenö/Ingadozó & Mérsékelt csökkenés & - \\
Aquila heliaca & Nincs adat & Növekvö/Növekvö & Nincs adat & - \\
Circus aeruginosus & Mérsékelt növekedés & Növekvö/Növekvő & Bizonytalan & - \\
Circus pygargus & Nincs adat & Csökkenö/Nem ismert & Bizonytalan & - \\
Falco vespertinus & Nincs adat & Csökkenö/Csökkenő & Nincs adat & - \\
Otis tarda & Nincs adat & Növekvö/Csökkenö & Nincs adat & Növekvő \\
Asio flammeus & Nincs adat & Ingadozó/Ingadozó & Nincs adat & - \\
Asio otus & Nincs adat & Nem ismert/Nem ismert & Nincs adat & - \\
Coracias garrulus & Nincs adat & Bizonytalan/Csökkenö & Nincs adat & - \\
Carduelis carduelis & Mérsékelt növekedés & Stabil/Stabil & Mérsékelt növekedés & - \\
\hline
\end{tabular}

A hazai agrártájhoz kötődő madárfajokat az alábbi adatokkal egészítem ki.

A parlagi sas (Aquila heliaca) trendje 2001-2009-es időszakban növekvő volt (HoRVÁTH et al., 2011).

A kékvércse (Falco vespertinus) populációs trendje 1997-2006 közötti erős csökkenését 2006-2009 között mérsékelt növekedés váltotta fel (PALATITZ et al., 2009). 20102013 között növekvő trendet mutat (PALATITZ et al., 2015).

A két fülesbagoly fajt (Asio flammeus, A. otus) tekintve, a réti fülesbagoly 2000-2012es időszakra ingadozó, az erdei fülesbagoly nem ismert kategóriába tartozott (BIRDLIFE, 2015). Viszont 1995-2002 között az utóbbi faj populációs trendje stabil volt (BIRDLIFE, 2004). Hazai releváns adatot nem találtam a két fajról.

A szalakóta (Coracias garrulus) esetében 1995-2002 között csökkenő volt a trend (KISS \& TOKODY, 2010), 2007-ben KovÁCS et al. (2008) stabil állapotot, Kiss et al. (2014) 2002-2013 között viszont már növekvő trendet állapítottak meg.

\subsection{AGRÁRTÁJHOZ KöTŐDŐ MADÁRFAJOK ÁLLOMÁNY HELYZETE MAGYARORSZÁGON}

A fajok európai állományadataihoz a BIRDLIFE (2015), a magyar adatokhoz az MME NOMENClATOR BizotTSÁG (2008) kiadványait használtam fel (2. táblázat). A táblázatban szereplő európai adatok egysége a pár, kivétel a következő fajok (félkövér betütípussal kiemelve) esetében: fürj (Coturnix coturnix), barna és hamvas rétihéja (Circus aeruginosus, C. pygargus) és a túzok (Otis tarda). A fürj és túzok esetében az éneklö, illetve dürgő kakasok száma, a rétihéják esetében a költő tojók kerültek feltüntetésre. A NOMENCLATOR BIZOTTSÁG (2008) csak a túzok esetében használt példány egységet.

A parlagi sas hazai állománynagyságát HORVÁTH et al. (2015) 155-165 párra becsülte.

A kékvércse hazai állománynagysága (PALATITZ et al., 2009) 2009-ben 1000-1100 pár volt. PALATITZ et al. (2015) szerint 2013-ban 1146 kékvércse pár kezdett költésbe, ez alapján 1200-1300 párra becsülték állományukat.

NAGY (2009) szerint a 2009-es téli számlálások alapján a hazai túzok populáció 1582 példány volt. A Bonni Jelentésben a faj populációja mininum1450, maximum 1645 példány 


\section{2. táblázat: Agrártájhoz kötődő madárfajok állomány helyzete}

Table 2: Breeding population size of farmland bird species

\begin{tabular}{|c|c|c|}
\hline \multirow{2}{*}{ Faj-Species } & \multicolumn{2}{|c|}{ Állománynagyság - Population estimate } \\
\hline & EU27/EU BirdLife (2015) & HU - MME Nomenclator (2008) \\
\hline Alectoris rufa & $5060000-7080000$ & - \\
\hline Perdix perdix & $1030000-2030000 / 1380000-2670000$ & $\min .10000, \max .20000$ \\
\hline Ciconia ciconia & $154000-164000 / 224000-247000$ & $\min .4800, \max .5600$ \\
\hline Falco tinnunculus & $315000-460000 / 409000-603000$ & $\min .3500$, max. 5000 \\
\hline Burhinus oedicnemus & $47600-77600 / 53$ 400-88 200 & $\min .150, \max .250$ \\
\hline Vanellus vanellus & $906000-1410000 / 1590000-2580000$ & $\min .20000$, max. 50000 \\
\hline Limosa limosa & 43 400-70 300/102 000-149000 & $\min .300, \max .1000$ \\
\hline Upupa epops & $1020000-2070000 / 1300000-2760000$ & $\min .10000, \max .17000$ \\
\hline Streptopelia turtur & $2340000-4050000 / 3150000-5940000$ & $\min .165000, \max .215000$ \\
\hline Alauda arvensis & $24100000-36800000 / 4400000-78800000$ & $\min .730000$, max. 900000 \\
\hline Calandrella brachydactyla & $1180000-1850000 / 4730000-9050000$ & - \\
\hline Melanocorypha calandra & 4200 000-6 770 000/10 300 000-21900000 & - \\
\hline Galerida cristata & 15200 000-19 300 000/17 700 000-24 500000 & $\min .190000$, max. 340000 \\
\hline Galerida theklae & $1750000-2840000 / 1750000-2840000$ & - \\
\hline Hirundo rustica & 22500 000-33 500 000/29000 000-48 700000 & $\min .220000$, max. 320000 \\
\hline Anthus campestris & $539000-967000 / 909000-1720000$ & $\min .13000$, max. 40000 \\
\hline Anthus pratensis & $4250000-7200000 / 9670000-15000000$ & - \\
\hline Motacilla flava & $4830000-8370000 / 9630000-16000000$ & $\min .150000$, max. 225000 \\
\hline Saxicola rubetra & $5330000-8380000 / 5330000-8380000$ & $\min .95000, \max .180000$ \\
\hline Saxicola torquata & $5330000-8380000 / 5790000-9310000$ & $\min .390000$, max. 515000 \\
\hline Oenanthe hispanica & $430000-1180000 / 1280000-3680000$ & - \\
\hline Sylvia communis & 8700 000-14 200 000/17 300 000-27800000 & min. 210000 , max. 320000 \\
\hline Lanius collurio & $3500000-6790000 / 7440000-14300000$ & $\min .540000, \max .670000$ \\
\hline $\begin{array}{l}\text { Lanius minor } \\
\text { Lanius senator }\end{array}$ & $\begin{array}{r}87700-165000 / 331000-896000 \\
1880000-2960000 / 1930000-3110000\end{array}$ & $\min .2800, \max .3700$ \\
\hline Corvus frugilegus & $3750000-6620000 / 8170000-14200000$ & $\min .20000, \max .23000$ \\
\hline Sturnus unicolor & 23900 000-30 600 000/23900 000-30600000 & - \\
\hline Sturnus vulgaris & 18300 000-33 500 000/28 800 000-52400000 & $\min .710000, \max .990000$ \\
\hline Passer montanus & $9890000-17400000 / 24000000-38200000$ & min. $2000000, \max .2800000$ \\
\hline Petronia petronia & $1330000-2170000 / 2140000-4620000$ & - \\
\hline Carduelis cannabina & 13800 000-19000 000/17 600 000-31900000 & $\min .85000, \max .150000$ \\
\hline Emberiza cirlus & $2340000-4230000 / 2490000-4650000$ & - \\
\hline Emberiza citrinella & 12800 000-19900 000/18 300 000-28000000 & $\min .630000$, max. 855000 \\
\hline Emberiza hortulana & $695000-1500000 / 3330000-7070000$ & - \\
\hline Emberiza melanocephala & $162000-481000 / 2470000-8160000$ & - \\
\hline Miliaria calandra & 14600 000-20 300 000/18 300 000-31300000 & $\min .165000$, max. 225000 \\
\hline Serinus serinus & $20000000-28500000 / 20900000-31500000$ & min. $160000, \max .245000$ \\
\hline Coturnix coturnix & $1270000-2980000 / 3320000-6720000$ & $\min .70$ 000, max. 94000 \\
\hline Aquila heliaca & $190-250 / 1,300-1,900$ & $\min .70, \max .90$ \\
\hline
\end{tabular}


A 2. táblázat folytatása - Table 2 cont.

\begin{tabular}{|c|c|c|}
\hline \multirow{2}{*}{ Faj-Species } & \multicolumn{2}{|c|}{ Állománynagyság - Population estimate } \\
\hline & EU27/EU BirdLife (2015) & HU - MME Nomenclator (2008) \\
\hline Circus aeruginosus & 37 700-87 800/99 300-184 000 & $\min .5200, \max .6700$ \\
\hline Circus pygargus & 15 600-21 400/54 500-92 200 & $\min .170$, max. 200 \\
\hline Falco vespertinus & $1800-2800 / 30300-63400$ & $\min .600, \max .900$ \\
\hline Otis tarda & 15 100-18 000/17 100-20 800 & $\min .1200$, max. 1300 \\
\hline Asio flammeus & 2 200-22 400/54 700-186000 & $\min .10$, max. 250 \\
\hline Asio otus & $115000-268$ 000/304 000-776 000 & $\min .6500$, max. 12000 \\
\hline Coracias garrulus & 11 900-22 800/37 700-79 200 & $\min .600, \max .1000$ \\
\hline Carduelis carduelis & $23500000-32500000 / 27800000-42700000$ & $\min .690000$, max. 910000 \\
\hline
\end{tabular}

(valószínűsíthető ez az egység, mivel nem találtam utalást erre vonatkozóan), de az adat a 2008-2012-es időszakra vonatkozik. Ugyanerre az időszakra a BIRDLIFE (2015) 500-609 dürgő kakas egyedet jelöl meg. ALONSO (2014) LÓRÁNT MIKLÓS szóbeli közlésére hivatkozva 1466 példányt közölt. becsülte.

A réti fülesbagoly esetében a BIRDLIFE (2015) hazai állománynagyságát 10-80 párra

KISS et al. (2014) a szalakóta hazai költő populáció nagyságát maximum 1100 párra becsülte.

\section{4. ÖSSZEGZÉS}

Az agrártájhoz kötődő madárfajok („farmland birds”) elmúlt évtizedekben megfigyelt állománycsökkenését (például SiRIWARDENA et al., 1998; PITKÄNEN \& TIAINEN, 2001; DONALD et al., 2006; REIF et al., 2008) az előző adatok is jól alátámasztják. Összegezve az adatbázisok információját (3. táblázat).

3. táblázat: A fajok állományváltozási terndjei az adatbázisok összegzése alapján Table 3. Summary of population trends based on the used databases

\begin{tabular}{ccccc}
\hline & $\begin{array}{c}\text { Csökkenő } \\
\text { Decreasing }\end{array}$ & $\begin{array}{c}\text { Növekvö } \\
\text { Increasing }\end{array}$ & $\begin{array}{c}\text { Stabil } \\
\text { Stable }\end{array}$ & $\begin{array}{c}\text { Bizonytalan } \\
\text { Uncertain }\end{array}$ \\
\hline EBCC (2012) & 22 & 8 & 6 & 3 \\
BIRDLIFE (2015) & 22 & 6 & 5 & - \\
MME MMM (2015) & 13 & 3 & 6 & 7 \\
\hline
\end{tabular}

A BIRDLIFE (2015) és a hazai adatbázis csak a stabil állománymutatóban egyeznek meg (Upupa epops). A két külföldi adatbázis 18 csökkenő és 4 növekvő trendü fajban egyezik meg. A két külföldi adatbázis 18 csökkenő trendü fajából 6 faj közös a hazai adatokkal (fél kövérrel szedve). Ezek az alábbiak:

- csökkenő trendü fajok (két külföldi adatbázis): Alectoris rufa, Perdix perdix, Falco tinnunculus, Vanellus vanellus, Limosa limosa, Streptopelia turtur, Alauda arvensis, Melanocorypha calandra, Galerida cristata, Anthus pratensis, Motacilla flava, 
Saxicola rubetra, Lanius senator, Sturnus vulgaris, Carduelis cannabina, Emberiza citrinella, Emberiza hortulana, Serinus serinus.

- növekvő trendü fajok (két külföldi adatbázis): Ciconia ciconia, Circus aeruginosus, Galerida theklae, Sturnus unicolor.

A mezei madárfajok állományaiban történt csökkenés okát leginkább a mezőgazdasági müvelésben bekövetkezett változásokban látják (például CHAMBERLAIN et al., 2000; DONALD et al., 2006), de nem szabad megfeledkezni egyes fajok (például Vanellus vanellus, Alauda arvensis, Streptopelia turtur) esetében a legális és illegális vadászatról sem (LUTZ, 2006; PETERSEN, 2006; BiRdLIFE, 2015). Emellett az állomány csökkenést befolyásolják a rövid és hosszú távú vonuló madárfajok esetében a telelő területen bekövetkezett változások (például időjárási szélsőségek, élőhelyek eltünése), amelyeket SANDERSON et al. (2006) vizsgálatukban kimutattak, vagy akár a klímaváltozás (ARCHAUX, 2003). A telelő területen végbement agrárintenzifikáció is negatív hatással van a vándorló fajok állományaira (SÖDERSTRÖM et al., 2003).

Természetesen a trendek megállapításához európai szinten megegyező módszertani felmérések szükségesek, amelyek kidolgozása nem egyszerü. Példaként hozható fel a fürj (Coturnix coturnix). Azonkívül ennél a fajnál az ellentmondó adatközlések (PUIGCERVER et al., 2012) miatt is nehéz az elmúlt évtized trendjét megállapítani. Az állománynagyságok esetében azonban láthattuk, hogy egyes adatbázisokban eltérőek is lehetnek a becslések egységei (pár/példány/kakas).

Az elmúlt évtizedben azonban sajnos bebizonyosodott, hogy a mezőgazdasági termelés intenzitása és az élővilág sokfélesége között roppant erős, ráadásul negatív összefüggés áll fenn: minél intenzívebb a termelés, annál szerényebb az élővilág (például KUJAWA, 2002; SARAH et al., 2004; Helm et al., 2006). Mind a hazai (BÁldi \& BATÁRY, 2011), mind az európai élővilág megőrzése érdekében ezért szükséges az EU-s agrárpolitikát újraértelmezni. Nagyon fontos, hogy a közép-európai (nemzetközi fontosságú) agrártájhoz kötődő madárfajok állományait fenntartsuk és a Nyugat-Európában még meglévő élőhelyeket megőrizzük, amihez egy extenzív mezőgazdasági rendszer kidolgozása javasolt.

\section{IRODALOMJEGYZÉK}

ALFORD, R.A. \& RICHARDS, S.J. (1999): Global amphibian declines: a problem in applied ecology. Annual Review of Ecology and Systematics 30: 133-165. http://dx.doi.org/10.1146/annurev.ecolsys.30.1.133

Alonso, J.C. (2014): The Great Bustard: past, present and future of a globally threatened species. Ornis Hungarica 22(2): 1-13. http://dx.doi.org/10.2478/orhu-2014-0014

Andreasen, C., Stryhn, H. \& Streibig, J.C.(1996): Decline of the Flora in Danish Arable Fields. Journal of Applied Ecology 33(3): 619-626. http://dx.doi.org/10.2307/2404990

ANDRÉN, H. (1994): Effects of Habitat Fragmentation on Birds and Mammals in Landscapes with Different Proportions of Suitable Habitat: A Review. Oikos 71(3): 355-366. http://dx.doi.org/10.2307/3545823

ARCHAUX, F. (2003): Birds and climate change. Vie et Milieu/Life \& Environment 53(1): 33-41.

ÁNGYÁN J., TARDY J. \& VAJNÁNÉ-MADARASSY A. (2003). Védett és érzékeny természeti területek mezőgazdálkodásának alapjai. Mezőgazda Kiadó, Budapest.

BÁldi A., BATÁRY P. \& ERDÖS S. (2005): Effects of grazing intensity on bird assemblages and populations of Hungarian grasslands. Agriculture, Ecosystems \& Environment 108(3): 251263. http://dx.doi.org/10.1016/j.agee.2005.02.006 
BÁLDI A. \& FARAGÓ S. (2007): Long-term changes of farmland game populations in a post-socialist country (Hungary). Agriculture, Ecosystems and Environment 118(1-4): 307-311. http://dx.doi.org/10.1016/j.agee.2006.05.021

BÁldi A. \& SzÉP T. (2009): A hazai állatvilág ökológiai állapota és jövője. Magyar Tudomány 170(1): 58-61.

BÁldi A. \& BATÁRY P. (2011): The past and future of farmland birds in Hungary. Bird Study 58(3): 365-377. http://dx.doi.org/10.1080/00063657.2011.588685

BENTON, T.G., VICKERY, J.A. \& WILSON, J.D. (2003): Farmland biodiversity: is habitat heterogeneity the key? Trends in Ecology and Evolution 18(4): 182-188. http://dx.doi.org/10.1016/S0169-5347(03)00011-9

BENTON, T.G. (2007): Managing farming's footprint on biodiversity. Science 315(5810): 341-342. http://dx.doi.org/10.1126/science. 1137650

BERG, A. \& PÄRT, T. (1994): Abundance of breeding farmland birds on arable and set-aside fields at forest edges. Ecography 17(2): 147-152. http://dx.doi.org/10.1111/j.1600-0587.1994.tb00087.x

BIBBY, C.J. (1994): Recent past and Future Extinctions in Birds. Philosophical Transactions: Biological Sciences 344(1307): 35-40. http://dx.doi.org/10.1098/rstb.1994.0048

BignAL, E., JONES, G. \& MCCRACKEN, D.I. (2001): Comment: future directions in agriculture policy and nature conservation. British Wildlife 13(1): 16-20.

BIRDLIFE INTERNATIONAL (2004): Birds in Europe: population estimates, trends and conservation status. BirdLife Conservation Series No.12. Cambridge.

BIRDLIFE INTERNATIONAL (2015): European Red List of Birds. Luxembourg: Office for Official Publications of the European Communities.

BURGESS, R.L. \& SHARPE, D.M. (1981): Forest island dynamics in man-dominated landscapes. Springer, New York.

CARLson, R. (1962): Silent Spring. Houghton Mifflin Co., Boston.

ChAmberlain, D.E. \& FulleR, R.J. (2000): Local extinctions and changes in species richness of lowland farmland birds in England and Wales in relation to recent changes in agricultural landuse. Agriculture, Ecosystems \& Environment 78(1):1-17. http://dx.doi.org/10.1016/S0167-8809(99)00105-X

Chamberlain, D.E., Fuller, R.J., Bunce, R.G.H., Duckworth, J.C. \& Shrubb, M. (2000): Changes in the abundance of farmland birds in relation to the timing of agricultural intensification in England and Wales. Journal of Applied Ecology 37(5): 771-788. http://dx.doi.org/10.1046/j.1365-2664.2000.00548.x

CHERNEL I. (1899): Magyarország madarai. Királyi Magyar Természettudományi Társulat, Budapest.

DEFRA (2014): Biodiversity 2020: A strategy for England's wildlife and ecosystem services. Indicators. <http:// www.gov.uk/defra > Letöltés: 2015.06.01.

DELIS, P.R., MUSHINSKY, H.R. \& MCCOY, E.D. (1996): Decline of some west-central Florida anuran populations in response to habitat degradation. Biodiversity and Conservation 5(12): 15791595. http://dx.doi.org/10.1007/BF00052117

DonALD, P.F., GREEN, R.E. \& HEATH, M.F. (2001): Agricultural intensification and the collapse of Europe's farmland bird populations. Proceedings of the Royal Society B 268(1462): 25-29. http://dx.doi.org/10.1098/rspb.2000.1325

Donald, P.F., PisAnO, G., RAYMENT, M.D. \& PAIN, D.J. (2002): The common agricultural policy, EU enlargements and the conservation of Europe's farmland birds. Agriculture, Ecosystems \& Environment 89(3): 167-182. http://dx.doi.org/10.1016/S0167-8809(01)00244-4

DONALD, P.F., SANDERSON, F.J., BURFIELD, I.J. \& VAN BOMMEL, F.P.J. (2006): Further evidence of continent-wide impacts of agricultural intensification on European farmland birds, 1990-2000. Agriculture, Ecosystems \& Environment 116(3-4):189-196. http://dx.doi.org/10.1016/j.agee.2006.02.007

DONÁZAR, J.A., NEGRO, J.J. \& HIRALDO, F. (1993): Foraging habitat selection, land-use changes and population decline in the lesser kestrel Falco naumanni. Journal of Applied Ecology 30(3): 515-522. http://dx.doi.org/10.2307/2404191 
EBCC (2012): European wild bird indicators in 2012. European Bird Census Council. $<$ http://ebcc.info $>$ Letöltés: 2015.06.01.

Eurostat (2010): Statistical Office of the European Communities. $<$ http://epp.eurostat.ec.europa.eu> Letöltés: 2015.06.01.

FAOSTAT (2010): Statistics division of the Food and Agriculture Organization of the United Nations. $<$ http:// faostat3.fao.org> Letöltés: 2015.06.01.

FARAGÓ, S., DitTrich, G., HorVÁth-HANGYA, K., WinkLeR, D. (2012): Twenty years of the grey partridge population in the LAJTA Project (Western Hungary). Animal Biodiversity and Conservation 35(2): 311-319.

FIRBANK, L.G. (2005): Striking a new balance between agricultural production and biodiversity. Annals of Applied Biology 146(2): 163-175.

FLOWERDEW, J.R. (1997): Mammal biodiversity in agricultural habitats. In: KIRKWOOD, R.C. (szerk.): Biodiversity and Conservation in Agriculture. British Crop Protection Council.

Fuller, R.J., Gregory, R.D, Gibbons, D.W., Marchant, J.H., Wilson, J.D., Baillie, R. \& CARTER, N. (1995): Population declines and range contractions among lowland farmland birds in Britain. Conservation Biology 9(6): 1425-1441. http://dx.doi.org/10.1046/j.1523-1739.1995.09061425.x

GALBRAITH, H. (1988): Effects of agriculture on the breeding ecology of lapwings Vanellus vanellus. Journal of Applied Ecology 25(2): 487-503. http://dx.doi.org/10.2307/2403839

GIBBS, J.P. (1998): Distribution of woodland amphibians along a forest fragmentation gradient. Landscape Ecology 13(4): 263-268. http://dx.doi.org/10.1023/A:1008056424692

GREGORY, R.D., NOBLE, D.G. \& CUSTANCE, J. (2004): The state of play of farmland birds: population trends and conservation status of lowland farmland birds in the United Kingdom. Ibis 146(Suppl. 2): 1-13.

Gregory, R.D., VAn Strien, A.J., Vorisek, P., GMelig Meyling, A.W., Noble, D.G., FopPen, R.P.B. \& GiBBOnS, D.W. (2005): Developing indicators for European birds. Philosophical Transactions of the Royal Society B 360(1454): 269-288. http://dx.doi.org/10.1111/j.1474-919X.2004.00358.x

GRoOMBRIDGE, B. (1992): Global Biodiversity: Status of the Earth's Living Resources. A Report Compiled by the World Conservation Monitoring Centre. Chapman \& Hall, London.

Henle, K., Alard, D., Clitherow, J., Cobb, P., Firbank, L., Kull, T., McCracken, D., Moritz, F., Niemelä, J., Rebane, M., Wascher, D., Watt, A. \& Young, J. (2008): Identifying and managing the conflicts between agriculture and biodiversity conservation in Europe-A review. Agriculture, Ecosystems and Environment 124(1-2): 60-71. http://dx.doi.org/10.1016/j.agee.2007.09.005

HERMAN O. (1901): A madarak hasznáról és káráról. A Magyar Királyi Földmivelésügyi Minister Kiadványa, Budapest.

HorvÁth M., Demeter I., FAtér I., Firmánszky G., Kleszó A., KovÁcs A., SZitTA T., Tóth I., ZALAI T. \& BAGYURA J. (2011): Population Dynamics of the Eastern Imperial Eagle (Aquila heliaca) in Hungary between 2001 and 2009. Acta Zoologica Bulgarica Suppl. 3: 61-70.

HorvÁth M., BAgyura J., DeÁK G., FATÉr I., FirmánSZKy G., JUHÁSz T., KlÉBERT A., PONGRÁCZ Á., Prommer M., SzelÉNYI B. \& VÁCZI M. (2015): A Parlagi sas-védelmi és MérgezésMegelőzési Munkacsoportok 2013. évi beszámolója. Heliaca 11: 6-9.

KISS O. \& TOKODY B. (2010): A szalakóta helyzete és védelmi intézkedések összefoglalása a DélAlföldön. Heliaca 8: 108-111.

KisS O., ELEK Z. \& MosKÁT Cs. (2014): High breeding performance of European Rollers Coracias garrulus in heterogeneous farmland habitat in southern Hungary. Bird Study 61(4): 496-505. http://dx.doi.org/10.1080/00063657.2014.969191

KLEIJN, D. \& SUTHERLAND, W.J. (2003). How effective are European agri-environment schemes in conserving and promoting biodiversity? Journal of Applied Ecology 40(6): 947-969. http://dx.doi.org/10.1111/j.1365-2664.2003.00868.x 
Kleijn, D., Berendse, F., Smit, R., Gilissen, N., Smit, J., BraK, B. \& Groeneveld, R. (2004): Ecological effectiveness of agri-environmental schemes in different agricultural landscapes in The Netherlands. Conservation Biology 18(3): 775-786. http://dx.doi.org/10.1111/j.1523-1739.2004.00550.x

KLEIJN, D. \& BÁLDI A. (2005): Effects of set-aside land on farmland biodiversity: comments on Van Buskirk and Willi. Conservation Biology 19(3): 963-966. http://dx.doi.org/10.1111/j.1523-1739.2005.00603.x

Kovács A., BAROV, B., OrHun, C. \& GALlO-ORSI, U. (2008): International Species Action Plan for the European Roller Coracias garrulus garrulus.

KuJAWA, K. (2002): Population density and species composition changes for breeding bird species in farmland woodlots in western Poland between 1964 and 1994. Agriculture, Ecosystems and Environment 91(1-3): 261-271. http://dx.doi.org/10.1016/S0167-8809(01)00221-3

Krebs, J.R., Wilson, J.D., Bradbury, R.B. \& SiriwardenA, G.M. (1999): The second silent spring? Nature 400: 611-612. http://dx.doi.org/10.1038/23127

LÁJER K. (1994): Gondolatok a természetvédelem biológiájáról. Természet világa 125(7): 290-293.

LiIRA, J., AAVIK, T., PARREST, O. \& ZOBEL, M. (2008): Agricultural sector, rural environment and biodiversity in the central and eastern European EU member states. Acta Geographica Debrecina Landscape \& Environment 2(1): 46-64.

LuTZ, M. (2006): European Union Management Plan 2007-2009, Turtle dove, Streptopelia turtur. European Commission, Brussels.

MME MONITORING KÖZPONT (2015): Mindennapi Madaraink Monitoring program (MME MMM). $<$ http://mmm.mme.hu> Letöltés: 2015.06.01.

MME NOMENCLATOR BIZOTTSÁG (2008): Magyarország madarainak névjegyzéke. Nomenclator avium Hungariae. Magyar Madártani és Természetvédelmi Egyesület, Budapest.

NAGY SZ. (2009): International single species action plan for the Western Palearctic population of Great Bustard Otis tarda tarda.

NEWTON, I. (2004): The recent declines of farmland bird populations in Britain: an appraisal of causal factors and conservation actions. Ibis 164(4): 579-600. http://dx.doi.org/10.1111/j.1474-919X.2004.00375.X

PAIN, D.J., HILL, D.A. \& MCCRACKEN, D.I. (1997): Impact of agricultural intensification of pastoral systems on the bird distributions in Britain 1970-1990. Agriculture, Ecosystems and Environment 64(1): 19-32. http://dx.doi.org/10.1016/S0167-8809(96)01126-7

Palatitz P., FehÉrVÁri P., Solt Sz. \& BAROV, B. (2009): European Species Action Plan for the Red-footed Falcon Falco vespertinus.

Palatitz P., Solt Sz., Horváth É., Fehérvári P., Kotymán L. \& Piross I. S. (2015): A Kékvércse-védelmi Munkacsoport 2013. évi beszámolója. Heliaca 11: 10-17.

PEACH, W. J., LOVETT, L. J., WotTON, S. R. \& JEFFS, C. (2001): Countryside stewardship delivers cirl buntings (Emberiza cirlus) in Devon, UK. Biological Conservation 101(3): 361-373. http://dx.doi.org/10.1016/S0006-3207(01)00083-0

Pechmann, J.H.K., Scott, R.D., Semlitsch, R.D., Caldwell, J.P., VitT, L.J. \& GibBons, J.W. (1991): Declining amphibian populations: the problem of separating human impacts from natural fluctuations. Science 253: 892-985. http://dx.doi.org/10.1126/science.253.5022.892

Perennou, C. (2009): European Union Management Plan 2009-2011, Common Quail, Coturnix coturnix. European Commission, Brussels.

Petersen, B.S. (2006): European Union Management Plan 2007-2009, Skylark, Alauda arvensis. European Commission, Brussels.

Petersen, B.S. (2009): European Union Management Plan 2009-2011, Lapwing, Vanellus vanellus. European Commission, Brussels.

PiCKETT, S.T.A. \& THOMPSON, J.H. (1978): Patch dynamics and the design of nature reserves. Biological Conservation 13(1): 27-37. http://dx.doi.org/10.1016/0006-3207(78)90016-2

PotTs, G.R. (1970): Recent changes in the farmland fauna with special reference to the decline of the grey partridge (Perdix perdix). Bird Study 17(2): 145-166. 
POTTS, G.R. (1986): The Partridge. Pesticides, predation and conservation. Collins, London.

POTTS, G.R. (1991): The environmental and ecological importance of cereal fields. In: FIRBANK, L.G., CARTER, N., DARBYShiRe, J.F. \& PotTS, G.R. (szerk.): The Ecology of Temperate Cereal Fields. Blackwell Scientific Publications, Oxford.

PotTs, G.R. (1997): Cereal farming, pesticides and grey partridges. In: PAIN, D. \& PIENKOWSKI, M. (szerk.): Farming and Birds in Europe. Academic Press, London.

PITKÄNEN, M. \& TIAINEN, J. (2001): Biodiversity of agricultural landscapes in Finland. BirdLife Finland, Conservation Series No.3. Helsinki.

Puigcerver, M., SARdÀ-PAlomera, F. \& RodríGUeZ-Teijeiro, J.D. (2012): Determining population trends and conservation status of the Common Quail (Coturnix coturnix) in Western Europe. Animal Biodiversity and Conservation 35(2): 343-352.

Reidsma, P., TeKelenburg, T., VAN DEN BerG, M. \& AlKemade, R. (2006): Impacts of land-use change on biodiversity: an assessment of agricultural biodiversity in the European Union. Agriculture, Ecosystems and Environment 114(1): 86-102. http://dx.doi.org/10.1016/j.agee.2005.11.026

Reif, J., VoríšeK, P., Stastny, K., BejCeK, V. \& Petr, J. (2008): Agricultural intensification and farmland birds: new insights from a central European country. Ibis 150(3): 596-605. http://dx.doi.org/10.1111/j.1474-919X.2008.00829.x

ROBINSON, R.A. \& SUTHERLAND, W.J. (2002): Post-war changes in arable farming and biodiversity in Great Britain. Journal of Applied Ecology 39(2): 157-176.

http://dx.doi.org/10.1046/j.1365-2664.2002.00695.x

SANDERSON, F.J., DONALD, P.F., PAIN, D.J., BURFIELD, I.J. \& VAN BOMMEL, F.P.J. (2006): Long-term population declines in Afro-Palearctic migrant birds. Biological Conservation 131(1): 93http://dx.doi.org/105. 10.1016/j.biocon.2006.02.008

SANDERSON, F.J., KuChARZ, M., JobDA, M. \& DONALD, P.F. (2013): Impacts of agricultural intensification and abandonment on farmland birds in Poland following EU accession. Agriculture, Ecosystems and Environment 168: 16-24. http://dx.doi.org/10.1016/j.agee.2013.01.015

SARAH, E.A., DURRELL, L.V. \& CLARKE, R.T. (2004): The buffer effect of non-breeding birds and the timing of farmland bird declines. Biological Conservation 120(3): 375-382. http://dx.doi.org/10.1016/j.biocon.2004.03.009

SCHLÄPFER, A. (1988): Populationsökologie der Feldlerche Alauda arvensis in der intensiv genutzten Agrarlandschaft. Ornithologischer Beobachter 85(4): 309-371.

SCHNEIDER, R.R. \& YoDZIS, P. (1994): Extinction Dynamics in the American Marten (Martes americana). Conservation Biology 8(4): 1058-1068. http://dx.doi.org/10.1046/j.1523-1739.1994.08041058.x

Siriwardena, G.M., BAIllie, S., BuCKLAND, S., FewSTer, R., MARChant, J. \& Wilson J. (1998): Trends in the abundance of farmland birds: a quantitative comparison of smoothed Common Birds Census indices. Journal of Applied Ecology 35(1): 24-43. http://dx.doi.org/10.1046/j.1365-2664.1998.00275.x

SisK, T.D., LAUNER, A.E., SwITKY, K.R. \& EHRLICH, P.R. (1994): Identifying Extinction Threats. Bioscience 44(9): 592-604. 10.2307/1312459

Smith, F.D., May, R.M., Pellew, R., Johnson, T.H. \& Walter, K.R. (1993): How much do we know about the current extinction rate? Trends in Ecology \& Evolution 8(10): 375-378. http://dx.doi.org/10.1016/0169-5347(93)90223-C

SOTHERTON, N.W. \& SELF, M. J. (2000): Changes in plant and arthropod biodiversity on lowland farmland: an overview. In: AEBISCHER, N. J., Evans, A.D., GRICE, P.V. \& VICKERY, J.A. (szerk.): Ecology and Conservation of Lowland Farmland Birds. British Ornithologists' Union, Tring.

SÖDERStRÖM, B., KIEMA, S. \& REID, R.S. (2003): Intensified agricultural land-use and bird conservation in Burkina Faso. Agriculture, Ecosystems and Environment 99(1-3): 113-124. http://dx.doi.org/10.1016/S0167-8809(03)00144-0 
StANDOVÁR T. \& PRIMACK, R.B. (2001): A természetvédelmi biológia alapjai. Nemzeti Tankönyvkiadó, Budapest.

StJernman, M., Green, M., Lindström, Å., Olsson, O., OtTVall, R. \& SMith, H.G. (2013): Habitat-specific bird trends and their effect on the Farmland Bird Index. Ecological Indicators 24: 382-391. http://dx.doi.org/10.1016/j.ecolind.2012.07.016

Stoate, C., BoAtman, N.D. BorRalho, R.J., Rio CaRVAlho, C., DE SNOO, G.R. \& Eden, P. (2001): Ecological impacts of arable intensification in Europe. Journal of Environmental Management 63(4): 337-365. http://dx.doi.org/10.1006/jema.2001.0473

SUTHERLAND, W. J. (2002): Openness in management. Nature 418: 834-835. http://dx.doi.org/10.1038/418834a

SVENNING, J.C. (2002): A review of natural vegetation openness in north-western Europe. Biological Conservation 104(2): 133-148. http://dx.doi.org/10.1016/S0006-3207(01)00162-8

SVEnsson, S. (1995): Monitoring Population Trends of Birds. The 1995 report. University of Lund.

SZÉP T., NAGY K., NAGY Zs. \& HALMOS G. (2012): Population trends of common breeding and wintering birds in Hungary, decline of long-distance migrant and farmland birds during 19992012. Ornis Hungarica 20(2): 13-63. http://dx.doi.org/10.2478/orhu-2013-0007

THOMAS, J.A. \& MORRIS, M.G. (1994): Patterns, mechanisms and rates of extinction among invertebrates in the United Kingdom. Philosophical Transactions of The Royal Society B: Biological Sciences 344(1307): 47-54. http://dx.doi.org/10.1098/rstb.1994.0050

Thomas, J. A., Telfer, M.G., Roy, D.B., Preston, C.D., Greenwood, J.J.D., Asher, J., Fox, R., Clarke, R.T. \& LAWTON, J.H. (2004): Comparative Losses of British Butterflies, Birds and Plants and the Global Extinction Crisis. Science 303(5665): 1879-1881. http://dx.doi.org/10.1126/science.1095046

Tilman, D., Fargione, J., WolfF, B., D'Antonio, C., Dobson, A., Howarth, R., Schindler, D., SCHLESINGER, W.H., SimBerlofF, D. \& SWACKHAMER, D. (2001): Forecasting agriculturally driven global environment change. Science 292(5515): 281-284.

http://dx.doi.org/10.1126/science.1057544

Tilman, D., Cassman, K.G., Matson, P.A., NAYlor, R. \& POlasky, S. (2002): Agricultural sustainability and intensive production practices. Nature 418: 671-677. http://dx.doi.org/10.1038/nature01014

Tryjanowski, P., Hartel, T., BÁldi, A., SZymański, P., Tobolka, M., Herzon, I., GOŁaWski, A., KonviČKA, M., HromadA, M., JerZAK, L., KUJAWA, K., LENDA, M., OrŁOWSKI, G., PANEK, M., SKÓRKA, P., Sparks, T., TWOREK, S., WUCZYŃSKI, A. \& ŻMIHORSKI, M. (2011): Conservation of farmland birds faces different challenges in Western and Central-Eastern Europe. Acta Ornithologica 46(1): 1-12. http://dx.doi.org/10.3161/000164511X589857

TsCharntKe, T., Klein, A.M., KRUESS, A., STEFFAN-DewENTER, I. \& THIES, C. (2005): Landscape perspectives on agricultural intensification and biodiversity - ecosystem service management. Ecology Letters 8(8): 857-874. http://dx.doi.org/10.1111/j.1461-0248.2005.00782.x

TUCKER, G.M. \& HEATH, M.F. (1994): Birds in Europe: their conservation status. BirdLife International, Conservation Series No. 3, Cambridge.

VAN STRIEN, A., PANNEKOEK, J. \& GIBBONS, D.W. (2001): Indexing European bird population trends using results of national monitoring schemes: a trial of a new method. Bird Study 48(2): 200213. http://dx.doi.org/10.1080/00063650109461219

VERA, F.W.M. (2000): Grazing Ecology and Forest History. CABI Publishing, Wallingford.

VERHULST, J., BÁLDI A. \& KLEIJN, D. (2004): The relation between land-use intensity and speciesrichness and abundance of birds in Hungary. Agriculture, Ecosystems and Environment 104(3): 465-473. http://dx.doi.org/10.1016/j.agee.2004.01.043

WILCOX, B.A. \& MURPHY, D.D. (1985): Conservation strategy: the effects of fragmentation on extinction. The American Naturalist 125(6): 879-887. http://dx.doi.org/10.1086/284386

WILSON, J.D., WhITTINGHAM, M.J. \& BRADBURY, R.B. (2005): The management of crop structure: a general approach to reversing the impacts of agricultural intensification on birds? Ibis 147(3): 453-463. http://dx.doi.org/10.1111/j.1474-919x.2005.00440.x 
WINKLER D. \& FARAGÓ S. (2011): Különböző agrárhabitatok fészkelő énekesmadár-közösségeinek vizsgálata a LAJTA Project területén. Ornis Hungarica 19: 183.

Wretenberg, J., Lindström, A., Svensson, S., Thierfelder, T. \& PART, T. (2006): Population trends of farmland birds in Sweden and England: similar trends but different patterns of agricultural intensification. Journal of Applied Ecology 43(6): 1110-1120.

http://dx.doi.org/10.1111/j.1365-2664.2006.01216.x

WRIGHT, H.E. (1974): Landscape development, forest fire and wilderness management. Science 186(4163): 487-495. http://dx.doi.org/10.1126/science.186.4163.487 